\title{
Copy Number Changes on the $X$ Chromosome in Women with and without Highly Skewed $\mathrm{X}$-Chromosome Inactivation
}

\author{
$\begin{array}{llll}\text { V. Jobanputra } & \text { B. Levy } & \text { A. Kinney } & \text { S. Brown } \\ & \text { M. Shirazi } & \text { C. Yu } & \text { M }\end{array}$ \\ J. Kline ${ }^{b, e, f}$ D. Warburton ${ }^{d}$
}

Departments of a Pathology and ${ }^{b}$ Epidemiology, Mailman School of Public Health, Columbia University, New York, N.Y., 'Departments of Obstetrics, Gynecology and Reproductive Science, University of Vermont, Burlington, Vt.,

${ }^{\mathrm{d}}$ Departments of Genetics and Development and Pediatrics, and e Sergievsky Center, Columbia University, and

${ }^{f}$ New York State Psychiatric Institute, New York, N.Y., USA

\section{Key Words}

Copy number changes $\cdot$ Microarray $\cdot$ Skewed X-inactivation

\begin{abstract}
Aim: To test the hypothesis that microdeletions or microduplications below the resolution of a standard karyotype may be a significant cause of highly skewed X-inactivation (HSXI) in women without a cytogenetically detected X-chromosome anomaly. Methods: Cases were women with HSXI, defined as $\geq 85 \%$ of cells in a blood sample with the same active allele at the HUMARA locus. The skewing in controls ranged from 50 to $<75 \%$. We performed an SNP microarray analysis using the Affymetrix 6.0 platform for 45 cases and 45 controls. Results: Cases and controls did not differ in the frequency of X-chromosome copy number changes $\geq 100$ $\mathrm{kb}$ or in the frequency of copy number changes that contained genes. However, one woman with HSXI $>90 \%$ in blood and left and right buccal smears had a 5.5-Mb deletion in Xp22.2p22.1. This deletion could affect the viability of male conceptions and may have led to the dysmorphology found in female carriers. Conclusion: HSXI in a blood sample is rarely due to X-chromosome copy number changes detectable by microarray.

Copyright $\odot 2012$ S. Karger AG, Basel
\end{abstract}

$\mathrm{X}$-chromosome inactivation (XCI), the process by which one of the two $\mathrm{X}$ chromosomes of a female embryo undergoes transcriptional silencing, occurs in early embryogenesis. Since inactivation occurs randomly between the two X chromosomes, in theory, $50 \%$ of cells will contain an active maternally inherited $\mathrm{X}$ chromosome and $50 \%$ of cells will contain an active paternally inherited X chromosome. Assuming 8-16 progenitor cells for a tissue [Fialkow, 1973; Amos-Landgraf et al., 2006] and a simple binomial model, highly skewed XCI (HSXI) $\geq 90 \%$ will occur by chance in $0.01-2.1 \%$ of women. Rarely, familial skewing involves mutations in XIST or other loci that affect the initial XCI [Plenge et al., 1997]. A second source of HSXI is initial inactivation that occurs in an unusually small pool of cells, as has been reported in monozygotic twins [Redonnet-Vernhet et al., 1996; Schroder et al., 1997] and in fetuses with confined placental mosaicism and trisomy rescue [Lau et al., 1997]. HSXI is thought to result most often from selection in a population of cells in which inactivation was initially random [Migeon, 1998]; the degree of selection varies among tissue types [Gale et al., 1994; Sharp et al., 2000; Bolduc et al., 2008]. HSXI often occurs in women with a structurally abnormal X chromosome in a manner that pre-

\section{KARGER}

Fax +4161306 1234

E-Mail karger@karger.ch

www.karger.com
(C) 2012 S. Karger AG, Basel

$1424-8581 / 12 / 1364-0264 \$ 38.00 / 0$

Accessible online at:

www.karger.com/cgr
Vaidehi Jobanputra

Department of Pathology, Columbia University

3959 Broadway, CHC-406

New York, NY 10032 (USA)

Tel. +1 212305 7373, E-Mail vj2004@ columbia.edu 
serves the normal X chromosome and autosomal dosage [Schmidt et al., 1991; Brown et al., 2001].

High-resolution microarrays can detect copy number changes (CNCs) in the $\mathrm{X}$ chromosome below the resolution of chromosome preparations. It is possible that CNCs contribute to the cause of otherwise unexplained HSXI. Their presence could have clinical implications for the health or reproductive success of women with HXSI. For example, a much-quoted paper [Pergeraro et al., 1997] described a large family in which a small deletion in Xq28 detected by linkage and BAC FISH segregated with both HSXI and recurrent miscarriages. This paper led to the hypothesis that HSXI is associated with recurrent miscarriage and/or trisomy. Initially, this result was supported by several other studies [Lanasa et al., 1999; Uehara et al., 2001; Beever et al., 2003], but recently, more systematic studies suggest that the hypothesis is invalid [Hogge et al., 2007; Warburton et al., 2009]. There are, however, no published data that directly assess the frequency with which microdeletions or duplications on the X chromosome are related to HSXI. To examine this question, we drew on a sample of women from a study of HSXI and trisomy [Warburton et al., 2009]. The research was approved by the institutional review boards of both Columbia University and the study hospital.

\section{Methods}

\section{Study Subjects}

In a previous study [Warburton et al., 2009], we recruited women with karyotyped miscarriages and an age-matched control group of women with live births. The primary aim of the study was to test the hypothesis that women with trisomic conceptions had a higher rate of skewed X-inactivation (in blood) than controls with live births or a chromosomally normal miscarriage. We found no difference in the frequency of HSXI $\geq 85 \%$ among any of the pregnancy groups. In the analyses reported here, the 45 women with HXSI consist of $6.4 \%$ of women with miscarriages and $5.9 \%$ of women with live births. As controls, we selected 45 women with skewing 50 to $<75 \%$ in blood. Controls were matched to cases for karyotype or live birth status to guard against potential confounding in the event that we detected an association between HSXI and trisomy.

We obtained a second blood sample for a PHA-stimulated karyotype from all women in the study. We also obtained left and right buccal smears for skewing analysis.

The karyotypes of all women were normal at a 550-band resolution except for one woman with a balanced autosomal reciprocal translocation. Mean maternal age was similar for cases and controls (35.2 and 34.3 years, respectively); $90 \%$ were non-Hispanic whites.

\section{HUMARA Assay for X-Inactivation Skewing}

The methods used for the HUMARA skewing assay and the calculation of the skewing percentage are described by Warburton et al. [2009]. Agreement between the skewing measures in blood and left and right buccal smears was poor (intraclass correlation coefficient $=0.41$ and 0.39 for left and right buccal smears, respectively, versus blood). Of 684 women heterozygous at the HUMARA locus, 3 women (0.4\%) had HSXI in all 3 tissue samples.

\section{SNP Oligonucleotide Microarray Analysis}

We performed copy number analysis using the Affymetrix Genome-Wide Human SNP Array 6.0 (Affymetrix, Santa Clara, Calif., USA). Sample preparation, hybridization, and scanning were performed according to the manufacturer's specifications. All samples met Affymetrix's recommended values for Contract Quality Control (>0.40) and Median Absolute Pairwise Difference score $(<0.35)$ for copy number analysis. Analysis was performed using the Affymetrix Chromosome Analysis Suite 1.0 (ChAS). We used a 'normal reference set' of DNA from 50 samples run on the Affymetrix SNP Array 6.0 in our laboratory. This dataset comprises 25 female and 25 male samples from apparently normal individuals with no phenotypic abnormalities and normal karyotypes. Samples were analyzed blind to skewing status.

Coordinates are based on the hg18 (NCBI36) genome build. This array contains 1.8 million genetic markers, including more than 906,600 single nucleotide polymorphisms (SNPs) and more than 946,000 probes for detection of copy number variation. The mean intermarker distance over all 1.8 million SNP and copy number markers combined is 1,599 bp. For the $\mathrm{X}$ chromosome, there are 37,902 SNP markers and 49,200 copy number probes with a mean intermarker distance of $1,776 \mathrm{bp}$ across the chromosome. Coverage is even except for areas of repetitive sequence that do not contain genes.

\section{Confirmation of Copy Number Changes}

FISH and real-time quantitative PCR (qPCR) were used to confirm CNCs detected by microarray analysis. FISH was performed according to our previously published protocol [Jobanputra et al., 2005]. For qPCR, we used a relative quantitation method described by Kindich et al. [2005]. This method uses the fluorescent dye SYBR Green I to analyze changes in DNA copy number in the research sample relative to a reference sample.

\section{Results}

We initially tabulated and visually examined in detail all CNCs $\geq 50 \mathrm{~kb}$ identified by the software. Many of these CNCs occurred in regions of known variation or included calls that looked spurious on examination of the raw data either because there were not enough probes in the region or the distribution of the probes was uneven. When we increased our threshold to $\geq 100 \mathrm{~kb}$, these problems were considerably reduced.

We attempted to validate all CNCs $\geq 100 \mathrm{~kb}$ and were able to confirm 7 CNCs. We failed to confirm one dupli- 
Table 1. Genes located in the duplicated and deleted regions of the $\mathrm{X}$ chromosome in case 556

\begin{tabular}{|c|c|c|}
\hline Gene symbol & OMIM associated disorder & $\begin{array}{l}\text { Escapes } \\
\text { inactivation }\end{array}$ \\
\hline \multicolumn{3}{|c|}{ Duplication Xp22.2 (13,487,048-13,737,322) } \\
\hline EGFL6 & & yes \\
\hline TCEANC & & yes \\
\hline$R A B 9 A$ & & yes \\
\hline TRAPPC2 & spondyloepiphyseal dysplasia tarda & yes \\
\hline OFD1/SGBS2 & $\begin{array}{l}\text { oral-facial-digital syndrome/ } \\
\text { Simpson-Golabi-Behmel syndrome }\end{array}$ & yes \\
\hline GPM6 & & yes \\
\hline \multicolumn{3}{|c|}{ Deletion Xp22.2p22.12 (13,876,566-19,370,512) } \\
\hline GEMIN8 & & unknown \\
\hline GLRA2 & & no \\
\hline$F A N C B$ & Fanconi anemia B & no \\
\hline MOSPD2 & & no \\
\hline$A S B 9$ & & unknown \\
\hline$A S B 11$ & & partial \\
\hline PIGA & $\begin{array}{l}\text { paroxysmal nocturnal } \\
\text { hemoglobinuria }\end{array}$ & no \\
\hline PIGF & & unknown \\
\hline PIR & & yes \\
\hline$B M X$ & & unknown \\
\hline ACE2 & & unknown \\
\hline TMEM27 & & yes \\
\hline CA5B & & yes \\
\hline ZRSR2 & & unknown \\
\hline AP1S2 & X-linked mental retardation 59 & yes \\
\hline$G R P R$ & & yes \\
\hline CTPS2 & & yes \\
\hline S100G & & unknown \\
\hline SYAP1 & & yes \\
\hline Cxorf15 & & yes \\
\hline$R B B P 7$ & & yes \\
\hline REPS2 & & partial \\
\hline NHS & Nance-Horan syndrome & partial \\
\hline SCML1 & & no \\
\hline$R A 12$ & & no \\
\hline BEND2 & & unknown \\
\hline SCML2 & & no \\
\hline CDKL5 & epileptic encephalopathy & ? partial \\
\hline$R S 1$ & retinoschisis & unknown \\
\hline PPEF1 & & unknown \\
\hline PHKA2 & hepatic glycogenosis & partial \\
\hline PDHA1 & Leigh syndrome & no \\
\hline GPR64 & & unknown \\
\hline MAP3K15 & & unknown \\
\hline
\end{tabular}

cation in Xq28 which occurred in 4 cases and 5 controls; this duplication appears to be an artifact of the array. We also failed to confirm 2 other gains, one of $114.8 \mathrm{~kb}$ and one of $133.7 \mathrm{~kb}$. These were also not convincing when the raw array data were examined.

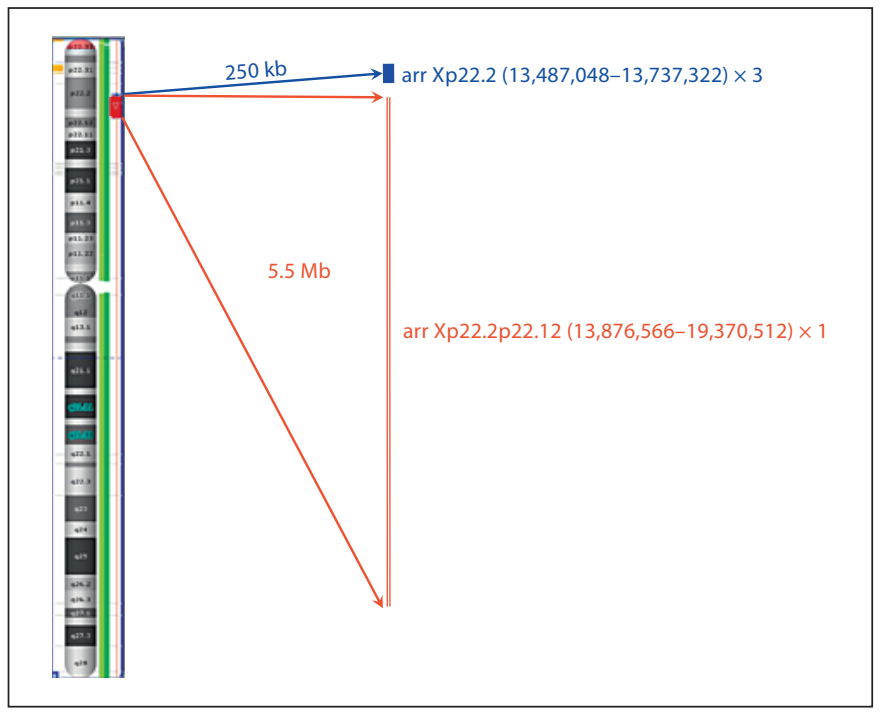

Fig. 1. Diagram showing a small $(250 \mathrm{~kb})$ duplication preceding a large (5.5 Mb) deletion in Xp22.2 demonstrated on an Affymetrix 6.0 SNP Array. Genes present in the copy number changes are shown in table 1 .

We considered that the 3 women with HSXI $\geq 85 \%$ in all 3 tissue samples had the greatest chance of having an $\mathrm{X}$ chromosome CNC. Two of these women had no detectable CNC. One woman (case 556) had a large 5.5-Mb deletion in Xp22.2p22.12 (bp 13,876,566-19,370,512), preceded by a smaller 250 -kb duplication (bp 13,487,04813,737,322; fig. 1). The deletion and duplication were confirmed by FISH analysis with BACs in the region. Table 1 shows, for each lesion, the known genes in the region, any disease associated with mutations in these genes, and what is known about inactivation status.

Table 2 summarizes the number and types of $\mathrm{CNCs}$ among women with HSXI and controls. We did not find significant differences between cases and controls in the frequency of CNCs, of CNCs with genes, or of women with CNCs. Three cases (6.7\%) and 4 controls (8.9\%) had at least one confirmed $\mathrm{CNC} \geq 100 \mathrm{~kb}$. If we consider only CNCs containing known genes, there are 2 cases (4.4\%) and no controls ( $0 \%$ ). Table 3 shows the confirmed CNCs found in cases and controls, known genes in the regions, disease associations and information about inactivation.

A search for $>15 \mathrm{Mb}$ stretches of homozygosity, suggesting uniparental disomy, was also negative except for 1 case. This case had a stretch of $16.3 \mathrm{Mb}$ of homozygosity on the X chromosome as well as multiple smaller regions on other chromosomes; such widespread homozygosity suggests consanguinity. 


\section{Discussion}

Among the 3 women with HSXI in all 3 tissue samples, we detected 1 woman with a large $\mathrm{X}$ chromosome duplication and deletion (case 556). We did not detect an increased frequency of CNCs among the 45 women with HSXI in blood compared with the 45 controls. Among cases, the frequency of $\mathrm{CNCs} \geq 100 \mathrm{~kb}$ was $6.7 \%$ (upper bound $95 \%$ confidence limit 14\%), the frequency of CNCs $\geq 100 \mathrm{~kb}$ which contained genes was $4.4 \%$ (upper bound 95\% confidence limit 10.5\%). This result argues against the view that microarray-detectable abnormalities of the X chromosome are a frequent cause of HSXI.

For case 556 (table 1), all the genes in the duplication and 14 of the 34 genes in the deletion are known to escape or partially escape inactivation [Carrel and Willard, 2005]. Genes escaping inactivation cannot lead to HSXI through selection for or against one allele. HSXI in two of this woman's tissues is probably attributable to inactivated genes in this large, gene-rich deletion. It seems probable that the deletion would be lethal in a male carrier. Her reproductive history includes, at the age of 34 years, an early miscarriage of a male with trisomy 6 , three unsuccessful intrauterine insemination attempts, one of which ended in a biochemical loss, followed by naturally conceived female monozygotic twins, born when the woman was 36 years old.

Mutations in several of the disease-associated genes in the deletion are known to show variable effects in hetero- zygous females. The woman who carries this deletion is in good health. She has large, cup-shaped ears and a missing bottom lateral incisor. One twin was born with transposition of the great vessels and is missing both upper lateral incisors. These features may result from hetero-

Table 2. Copy number changes ${ }^{a}$ for women with and without highly skewed $(\geq 85 \%) \mathrm{X}$-chromosome inactivation

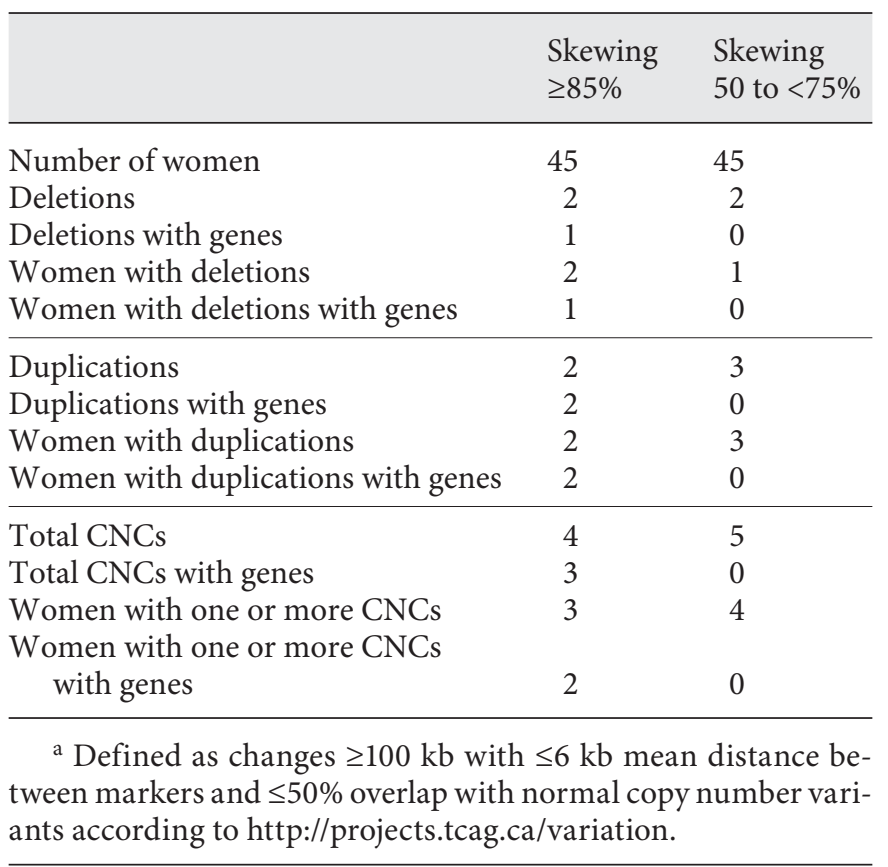

Table 3. X-chromosome copy number changes in 45 women with highly skewed X-inactivation in blood and 45 control women without skewed X-inactivation

\begin{tabular}{|c|c|c|c|c|c|c|c|c|c|}
\hline $\begin{array}{l}\text { Sample } \\
\text { number }\end{array}$ & $\begin{array}{l}\text { Band } \\
\text { start }\end{array}$ & $\begin{array}{l}\text { Base pair } \\
\text { start }\end{array}$ & $\begin{array}{l}\text { Size } \\
\mathrm{kb}\end{array}$ & $\begin{array}{l}\text { Gain or } \\
\text { loss }\end{array}$ & $\begin{array}{l}\text { CNV overlap } \\
\%\end{array}$ & Genes & $\begin{array}{l}\text { OMIM } \\
\text { disorder }\end{array}$ & Inactivated? & $\begin{array}{l}\text { Skewing } \\
\%\end{array}$ \\
\hline \multicolumn{10}{|c|}{ Cases with a skewing ratio $\geq 85 \%$} \\
\hline 556 & $\mathrm{p} 22.2$ & $13,487,048$ & 250 & gain & 0 & many & see table 1 & see table 1 & 94.9 \\
\hline 621 & $\mathrm{p} 11.1$ & $58,342,010$ & 146 & loss & 15 & none & none & NA & 89.9 \\
\hline \multicolumn{10}{|c|}{ Controls with a skewing ratio 50 to $<75 \%$} \\
\hline 384 & $\mathrm{q} 26.2$ & $130,643,660$ & 164 & gain & 0 & none & none & NA & 53.9 \\
\hline 645 & p22.33 & $1,772,233$ & 246 & gain & 0 & none & none & NA & 71.6 \\
\hline 657 & $\mathrm{q} 21.1$ & $78,947,125$ & 100 & gain & 32 & none & none & NA & 62.0 \\
\hline
\end{tabular}

$\mathrm{CNV}=$ Copy number variant; $\mathrm{NA}=$ not applicable. 
zygosity for a deletion of the NHS gene, where mutation is associated with Nance-Horan syndrome (MIM ID No. 302350), or from other genes deleted in the region. We were unable to study $\mathrm{X}$-inactivation in the twins nor could we study the woman's parents to determine whether or not the mutation is de novo. The woman's only sibling is a sister who has 5 sons, making it unlikely that she is a carrier.

In the total sample of cases and controls, we observed 5 confirmed duplications and 4 confirmed deletions. Only 2 duplications (cases 556 and 216) and 1 deletion (case 556) contained genes. Although there are genes with disease associations in the duplication of case 216, these are in a region that escapes inactivation and therefore cannot be associated with skewing.

It is unlikely that any of the observed CNCs could have affected X-inactivation skewing except for the large deletion found in case 556. Our study excludes as unlikely frequencies of gene-containing CNCs $\geq 100 \mathrm{~kb}$ in excess of $10.5 \%$ (upper bound of $95 \%$ confidence limit) among women with HSXI in blood. From both a clinical and biologic standpoint, this upper bound is low enough to indicate that $\mathrm{CNCs} \geq 100 \mathrm{~kb}$ are not a common cause of HSXI.

Among the 3 cases with HSXI documented in more than one tissue, we found one woman with a large $\mathrm{X} \mathrm{mi-}$ crodeletion that could be the cause of her skewed inactivation status and of minor dysmorphisms. This CNC could also affect future pregnancies, since males with the affected $\mathrm{X}$ are likely to be abnormal. Thus, for women with HSXI in multiple tissues, microarray testing may reveal clinically relevant information. Validation of this recommendation would require replication and confirmation of our finding in another sample of women with HSXI in multiple tissues. However, the rarity of women with HSXI in more than one tissue $(0.4 \%$ in our total sample of women) limits the opportunities for formal replication.

In clinical practice, it is very rare to test skewing in any tissue other than blood. Thus, our results apply to most women reported to have HSXI. If family or reproductive history (e.g. premature ovarian failure, miscarriage, or neonatal death of male conceptions) suggests that skewing due to $\mathrm{CNCs}$ on the $\mathrm{X}$ chromosome is relevant, confirmation of skewing in a second tissue should precede microarray testing.

\section{Acknowledgments}

This work was supported by grants from the National Institutes on Child Health and Development (R01 HD 042725 to D.W. and R01 HD 053814 to J.K.). V.J. received support from a grant from the National Center for Research Resources (KL2RR024157). We would also like to thank the women who participated in the original study and the colleagues at the Valley Hospital in Ridgewood, N.J., USA.

\section{References}

Amos-Landgraf JM, Cottle A, Plenge, RM, Friez Carrel L, Willard HF: X-inactivation profile re$\mathrm{M}, \mathrm{Sch}$ artz CE, et al: X chromosome-inactivation patterns of 1,005 phenotypically unaffected females. Am J Hum Genet 79:493499 (2006)

- Beever CL, Stephenson MD, Penaherrera MS, Jiang RH, Kalousek DK, et al: Skewed Xchromosome inactivation is associated with trisomy in women ascertained on the basis of recurrent spontaneous abortion or chromosomally abnormal pregnancies. Am J Hum Genet 72:399-407 (2003).

-Bolduc V, Chagnon P, Provost S, Dubé MP, Belisle C, et al: No evidence that skewing of $\mathrm{X}$ chromosome inactivation patterns is transmitted to offspring in humans. J Clin Invest 118:333-341 (2008).

- Brown LY, Alonso ML, Yu J, Warburton D, Brown S: Prenatal diagnosis of a familial Xq deletion in a female fetus: a case report. Prenat Diagn 21:27-30 (2001). veals extensive variability in X-linked gene expression in females. Nature 434:400-404 (2005).

-Fialkow PJ: Primordial cell pool size and lineage relationships of five human cell types. Ann Hum Genet 37:39-48 (1973).

Gale RE, Wheadon H, Boulos P, Linch DC: Tissue specificity of X-chromosome inactivation patterns. Blood 83:2899-2905 (1994).

Hogge WA, Prosen TL, Lanasa MC, Huber HA, Reeves MF: Recurrent spontaneous abortion and skewed X-inactivation: is there an association? Am J Obstet Gynecol 196:384 e381386; discussion 384 e386-388 (2007).

Jobanputra V, Sebat J, Troge J, Chung W, Anyane-Yeboa K, et al: Application of ROMA (representational oligonucleotide microarray analysis) to patients with cytogenetic rearrangements. Genet Med 7:111-118 (2005).
Kindich R, Florl AR, Jung V, Engers R, Müller M, et al: Application of a modified real-time PCR technique for relative gene copy number quantification to the determination of the relationship between NKX3.1 loss and $M Y C$ gain in prostate cancer. Clin Chem 51 : 649-652 (2005).

Lanasa MC, Hogge WA, Kubik CJ, Blancato J Hoffman EP: Highly skewed X-chromosome inactivation is associated with idiopathic recurrent abortion. Am J Hum Genet 65:252254 (1999).

Lau AW, Brown CJ, Penaherrera M, Langlois S, Kalousek DK, Robinson WP: Skewed Xchromosome inactivation is common in fetuses or newborns associated with confined placental mosaicism. Am J Hum Genet 61: 1353-1361 (1997).

Migeon BR: Non-random X chromosome inactivation in mammalian cells. Cytogenet Cell Genet 80:142-148 (1998). 
Pergeraro E, Whitaker J, Mowery-Rushton P, Surti U, Lanasa M, Hoffman EP: Familial skewed $\mathrm{X}$ inactivation: a molecular trait associated with high spontaneous abortion rate maps to Xq28. Am J Hum Genet 61:160170 (1997).

$\checkmark$ Plenge RM, Hendrich BD, Schwartz C: A promoter mutation in the XIST gene in two unrelated families with skewed X-chromosome inactivation. Nat Genet 17:353-356 (1997).

Redonnet-Vernhet I, Ploos van Amstel JK, Jansen RP, Wevers RA, Salvayre R, Levade T: Uneven $\mathrm{X}$ inactivation in a female monozygotic twin pair with Fabry disease and discordant expression of a novel mutation in the alpha-galactosidase A gene. J Med Genet 33: 682-688 (1996).
Schmidt M, Du Sart D, Kalitsis P, Fraser N, Leversha $\mathrm{M}$, et al: $\mathrm{X}$ chromosome inactivation in fibroblasts of mentally retarded female carriers of the fragile site Xq27.3: application of the probe M27 beta to evaluate X inactivation status. Am J Med Genet 38:411-415 (1991).

Schroder W, Wulff K, Wollina K, Herrmann FH: Haemophilia B in female twins caused by a point mutation in one factor IX gene and nonrandom inactivation patterns of the Xchromosomes. Thromb Haemost 78:13471351 (1997).
Sharp A, Robinson D, Jacobs P: Age- and tissuespecific variation of $\mathrm{X}$ chromosome inactivation ratios in normal women. Hum Genet 107:343-349 (2000)

Uehara S, Hashiyada M, Sato K, Sato Y, Fujimori K, Okamura K: Preferential X-chromosome inactivation in women with idiopathic recurrent pregnancy loss. Fert Steril 76:908914 (2001).

Warburton D, Kline J, Kinney A, Yu CY, Levin B, Brown S: Skewed X chromosome inactivation and trisomic spontaneous abortion: no association. Am J Hum Genet 85:179-193 (2009). 